\title{
Toponyms for centers of endemism in Madagascar
}

\author{
Lucienne Wilmé, Mamy Ravokatra', Rainer Dolch", \\ Derek Schuurman"', Eric Mathieu" ${ }^{\prime \prime}$, Harald Schuetz ${ }^{v}$ \\ and Patrick O. Waeber ${ }^{\mathrm{VI}}$
}

\author{
Correspondence : \\ Lucienne Wilmé \\ Missouri Botanical Garden \\ Madagascar \\ E-mail: lucienne.wilme@gmail.com
}

\begin{abstract}
A biogeographical model was proposed in 2006 to explain the centers of endemism and the importance of riparian forest of some watersheds as refuges or dispersal corridors during paleoclimatic oscillations. Here, we consider these geographical features highlighting their biological and sociocultural importance. We explain the etymology or eponymy of the major rivers of the retreat-dispersal watersheds, i.e., the drainage basins of Bemarivo, Antainambalana, Mangoro, Manampatrana, Mananara South, Mandrare, Onilahy, Mangoky, Tsiribihina, Betsiboka, Maevarano, Sambirano, and Mahavavy North. We propose a toponymy for each of the 15 centers of endemism and highlight their peculiarities. We named the centers of endemism of Vohimarina, Masoala, Analanjirofo, Tanala, Manombo, Anosy, Ranopiso, Karimbola, Mikea, Menabe, Melaky, Sofia, Ampasindava, Ankify, and Ankarana.

We illustrate each center of endemism with a flagship species and report on its natural and cultural histories, and conservation.
\end{abstract}

\section{RÉSUMÉ}

Un modèle biogéographique a été proposé en 2006 pour expliquer les centres d'endémisme de la biodiversité et l'importance des ripisylves de certains bassins versants en tant que refuges ou couloirs de dispersion au cours des oscillations paléoclimatiques. Ici, nous considérons ces dispositifs géographiques en soulignant leur importance biologique et socio-culturelle. Dans un premier temps, nous expliquons la toponymie ou l'éponymie des grands fleuves des bassins refuges et de dispersion, à savoir les bassins de la Bemarivo, de l'Antainambalana, du Mangoro, de la Manampatrana, de la Mananara du Sud, du Mandrare, de I'Onilahy, du Mangoky, de la Tsiribihina, de la Betsiboka, de la Maevarano, du Sambirano et de la Mahavavy du Nord. Puis nous proposons une toponymie pour chacun des 17 centres et sous-centres d'endémisme en justifiant leurs particularités. Nous retenons ainsi les centres d'endémisme de Vohimarina, de I'Atsinanana (dont Masoala et Analanjirofo), Tanala, de Manombo, de I'Anosy, d'Ala maika (dont Ranopiso, Karimbola et Mikea), du Menabe, du Melaky, de la Sofia, d'Ampasindava, d'Ankify et de I'Ankarana. Nous illustrons chacun des centres d'endémisme avec une espèce symbolique et rapportons des aspects de son histoire naturelle et culturelle ainsi que de sa conservation.

\section{INTRODUCTION}

Madagascar has a surface of $587,040 \mathrm{~km}^{2}$, of which about $18 \%$ is covered with forests. These forests are found from the coast to the highest mountains ( $>2,000 \mathrm{~m}$ above sea level), and represent a hyper-variable environment (Dewar and Richard 2007) with a diverse set of forest ecosystems (Moat and Smith 2007). Riparian forests along streams and rivers are found all over Madagascar and are especially obvious in the drier regions of southern, western and northern Madagascar. Madagascar is renowned for its biodiversity and high degree of local endemism ( $84 \%$ for land vertebrates, $86 \%$ for macro-invertebrates, > $90 \%$ for vascular plants) (Goodman and Benstead 2005). Remarkably, a majority of the island's endemic species are forest dwelling with ca. $90 \%$ for land mammals, and almost $78 \%$ for endemic bird species (Raherilalao and Wilmé 2008). As examples, among the genera of Brown lemurs (Eulemur spp.) or Mouse lemurs (Microcebus spp.), several species have radiated and adapted to a variety of these forest ecosystems on the eastern and western slopes of the island. Eastern and western Madagascar have long been the main divisions for flora and fauna (Perrier de la Bâthie 1921, Humbert 1965, Cornet et Guillaumet 1976), and more recently, as has been shown to be the case with the Mouse lemurs, a general northern and southern division has also emerged (Martin 1972, Yoder 2003).

Birds and mammals evolved during the Cenozoic era during which Madagascar was isolated from any other continental land mass (Krause 2010). There are no palaeontological records for these vertebrate groups in Madagascar, with exception of some 
BOX 1: Glossary

\begin{tabular}{|l|l|}
\hline Center of endemism & $\begin{array}{l}\text { An area exhibiting high levels of endemic species, i.e., species confined to the area and found } \\
\text { nowhere else. }\end{array}$ \\
\hline Drainage divide & $\begin{array}{l}\text { The line separating neighbouring watersheds. We consider that the crest lines between adjacent } \\
\text { watersheds are the only 'natural' lines. In hilly areas, usually in the upper watershed, the divide lies } \\
\text { along the topographical peaks and ridges; in flat areas, usually in the lower part of the watershed, } \\
\text { the line can be invisible. }\end{array}$ \\
\hline Dispersion & Species movement away from an existing population \\
\hline Local endemism & For species only encountered in a defined area of small size \\
\hline Headwaters & $\begin{array}{l}\text { The source of a river or stream; it refers to the furthest and highest place in that river from its } \\
\text { estuary or confluence. }\end{array}$ \\
\hline Palaeoroute & Route of dispersion at the geological scale, here limited to the Plio-Quaternary. \\
\hline Refuge & A location where a relict population of a once more widespread species survives. \\
\hline Watershed or catchment /drainage / water basin & $\begin{array}{l}\text { An area of land delimitated by crest lines where surface water from rain converges to a single } \\
\text { point which is the exit of a basin, and could be the estuary, a lake or a wetland, the ocean, or } \\
\text { another river. }\end{array}$ \\
\hline
\end{tabular}

recent subfossils dating mostly to the last 10,000 years (Krause 2010). The study of the evolution of endemic taxa in Madagascar is based on phylogenetic and molecular approaches, which have gained momentum over the last two decades (e.g., Yoder and Nowak 2006, Horvath et al. 2008, Reddy et al. 2012). A mechanistic model (Wilmé et al. 2006) uses topography and riparian systems (i.e., riparian forests, rivers and headwaters at different elevations) combined with varying climate as principal factors to explain biogeographical patterns of local endemism. In periods of climatic change - especially during aridity - some populations may die off, others become isolated and adapt accordingly, and others may migrate and find refuge in riparian forests along rivers, which have their headwaters in the highest mountains. In times where climate shifts towards increased humidity, the reverse pathway occurs, with riparian forests expanding to lower elevations and species dispersing accordingly. Riparian forests of a watershed are therefore structural and functional pathways for species to retreat to and to disperse from. The smaller watersheds that are between these refugia-dispersion routes constitute a center of endemism (Wilmé et al. 2006).

There are only three mountainous regions in Madagascar that exceed the 2000 m elevation: Tsaratanana in the north reaching $2876 \mathrm{~m}$ above sea level, Ankaratra in central Madagascar to $2642 \mathrm{~m}$ a.s.I., and Andringitra to $2658 \mathrm{~m}$ a.s.l. in the south. The rivers with headwaters above $2000 \mathrm{~m}$ are the Bemarivo, Mahavavy, Sambirano, and Maevarano in the north, the Mangoro, Betsiboka, and Tsiribihina in central Madagascar, and the Manampatrana, Mananara, and the Mangoky rivers in the south. Wilmé et al. (2006) divided Madagascar into 12 centers of endemism, two of which are here split further (Figure 1). The objectives of this study are to name for the first time these centers of endemism. Allocating names for these centers that reflect and emphasize their particular biological and socio-cultural values will serve to link the importance of biodiversity with cultural history, and allow for the facilitation of communication between policy-makers and conservationists, when planning and managing land. We also include the names and etymology of the watersheds described in Wilmé et al. (2006), and where possible explore the reason for the current toponymy. We include a list of species that reflect the importance and character of each of the centers of endemism.

\section{ETYMOLOGY AND TOPONYMY}

People need to give names to sites or areas to be able to communicate, identify and locate them in space (Kadmon 2000). Geographical names or labels often have a meaning inspired by a location's topography, prominent landscape feature(s), hydrography, or characteristic fauna and flora. A toponym usually reduces the multidimensional complexity of a locale and abstracts the dimensions to one name representing the fundamental traits of it (Conedera et al. 2007). Table 1 lists the already existing toponymy of rivers as mentioned on the topographical

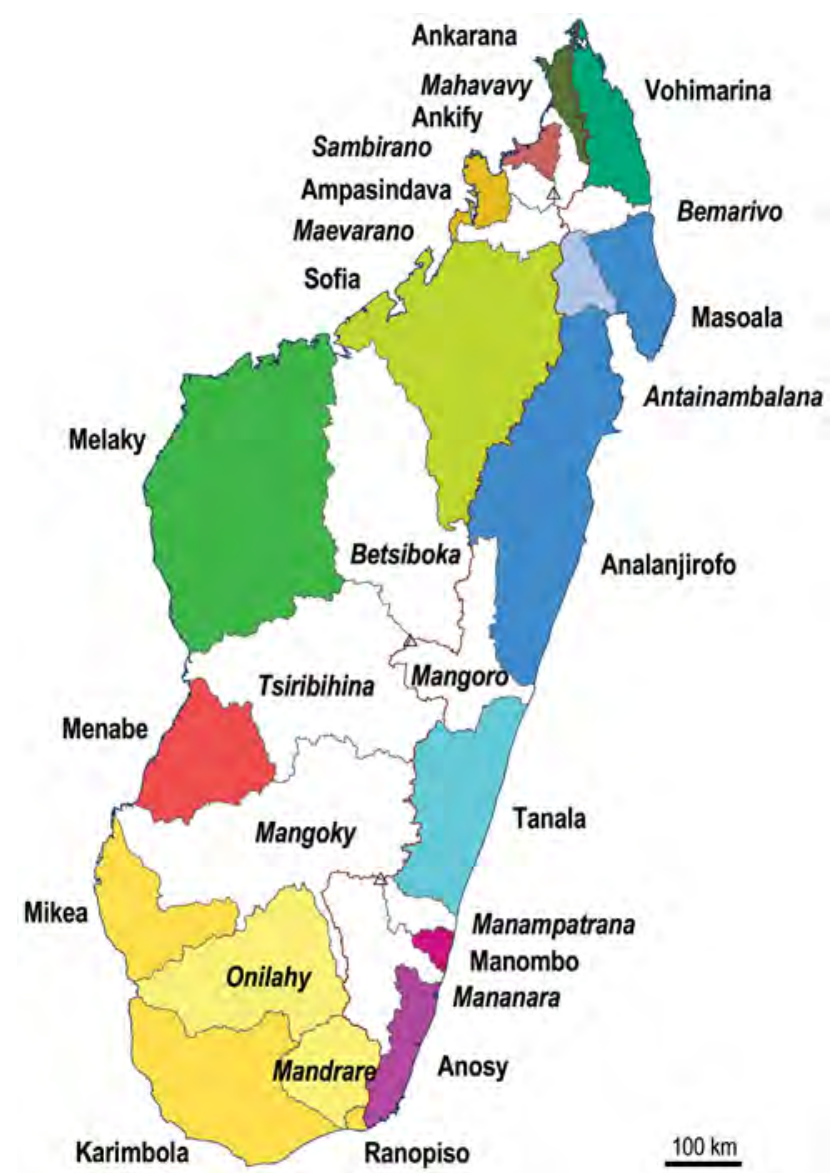

FIGURE 1. Retreat-dispersion watersheds (white - italic) and centers of endemism (colored - regular) 
maps produced by Foiben-Taosarintanin'i Madagasikar - FTM (i.e., map at a scale of 1:500,000) from the Institut Géographique et Hydrographique de Madagascar which were used by Wilmé et al. (2006) for the identification of the 15 centers of endemism; here we present new names for these centers of endemism; both elaborating on the origin and meaning of the words, which in the greater part are from Malagasy. Some authors have published translations and/or etymologies of Malagasy toponyms (Grandidier 1895, Molet 1957). In most instances, the toponyms are regional and therefore only have a meaning in a regional context. We gathered information from people across Madagascar during fieldwork for biodiversity assessments by means of informal discussions with locals and present our results in Table 1 and the remainder of this section.

To decide which faunal and/or floral species could characterize a respective center of endemism, the following criteria have been applied:

1. A species needs to be locally endemic (Box 1).

2. A clear taxonomic circonscription must exist for a species (e.g., the taxon has been studied in terms of ecology, genetics, anatomy, and current distribution.

3. A species must represent an extant, not an extinct taxa (i.e., subfossils are not considered here).

4. The distribution of a species should be as widespread within a center of endemism as possible, i.e., described with confirmed data points (in section Flagship species denoted as 'number of data points'); see also Figure 2.

5. The species must be scientifically well documented (i.e., referred to in scientific publications; in section Flagship species denoted as 'number of references'). For this, a database research was performed using Noe4D database (Hertu and Elouard 2001, Wilmé et al. 2006) with more than 8,000 publications on Madagascar biodiversity. Noe4D database is a 4D-based software allowing for structured composite, keyword and cluster index search to manage ecological and taxonomical data regarding the terrestrial vertebrates of Madagascar. In addition, we gathered data through a structured search of published peer-reviewed literature in the online catalogues and search engines Google scholar, ISI Web of Knowledge, CAB Direct, and Tropicos

The search for literature on this topic began in November 2011, and ended in March 2012.

In the following the 15 centers of endemism (Table 2) will be named and an etymology and eponomy provided. Each center of endemism is located on Figure 1.

\section{Center of Endemism: VOHIMARINA}

Etymology: Malagasy vohitra = hill, village, and marina = fair, honest, stable, unchanged. For the scenic coastal town of Vohimarina, also known as Iharana or Vohemar. Vohimarina is one of Madagascar's rare natural ports but is also renowned as an important archaeological site of the ancient Rasikajy culture, their distinctively appointed tombs, and carved chlorite-schist vessels, often with three legs (Vérin 1986).

\section{Center of Endemism: MASOALA}

Etymology: Malagasy maso = eye, ala = forest. The name also refers to the Masoala peninsula and more recently to Masoala National Park, which protects 220,500 ha of humid and littoral forests (Moat and Smith 2007).

\section{Center of Endemism: ANALANJIROFO}

Etymology: Malagasy ala $=$ forest, jirofo $=$ clove, to refer to those eastern forests where cloves have become a cash crop. Analanjirofo is also the name of an official Region since 4 October 2009.

Formerly the refuge of pirates (Dewar et al. 2010), most of the original lowland vegetation has made way for lychees, cloves, vanilla and cinnamon. Although containing several protected areas such as Mantadia, Zahamena, Ambatovaky,

TABLE 1. Etymology of the refuge-dispersion watersheds as presented in Wilmé et al. (2006) for headwaters at high altitudes.

\begin{tabular}{|c|c|}
\hline Toponymy & Etymology, Eponymy, Explanation \\
\hline Bemarivo & $\begin{array}{l}\text { Malagasy be }=\text { plenty, and marivo = shallow. To explain the many places where it is easy to cross the river because of shallow } \\
\text { waters. }\end{array}$ \\
\hline Antainambalana & Also known as Antaimbalana. Malagasy an = place, tai = excrement, dung, and mivalana = flowing downstream. \\
\hline Mangoro & Malagasy mangoro = rolling a lot of water (Molet 1957) \\
\hline Manampatrana & Malagasy manana $=$ to have, and fatrana = pasture for zebus \\
\hline Mananara Sud & Malagasy mananara = showing rocks (Dandouan 1922) \\
\hline Mandrare & $\begin{array}{l}\text { Malagasy mandry = sleeping, and southern Malagasy dialect areo = you; one of the co-authors (SMSR) settled a camp next to } \\
\text { the river in the 1990s before crossing the shallow river to conduct a tortoise inventory. On his way back, he couldn't cross the river } \\
\text { anymore because the water rose significantly. It is expected that people have often to sleep along the banks of the Mandrare until } \\
\text { the water level is receding. In August } 2005 \text {, under clear blue sky, another co-author (LW) observed the Mandrare growing from a } \\
\text { tiny stream to a } 30 \mathrm{~m} \text { wide river in just } 15 \text { minutes. }\end{array}$ \\
\hline Onilahy & Malagasy ony $=$ large river, lahy $=$ male or man \\
\hline Mangoky & From a western Malagasy dialect mangôky = that digs \\
\hline Tsiribihina & Also known as Tsitsobohina. Malagasy where one does not dive (Dandouan 1922) \\
\hline Betsiboka & Malagasy be $=$ big, tsy $=$ not, and boka = leprous or insipid \\
\hline Maevarano & Malagasy maeva = beautiful, and rano = water. Maeva can also be a name for a girl. \\
\hline Sambirano & $\begin{array}{l}\text { Malagasy samby or samy = each, and rano = water. Litterally, a river with two types of water: fresh water upstream and brackish } \\
\text { water at the mouth (Grandidier 1895) }\end{array}$ \\
\hline Mahavavy North & $\begin{array}{l}\text { Malagasy maha }=\text { for, as a prefix, and vavy = female. Also suggested as 'castrate' for the large number of crocodiles in its waters } \\
\text { (Grandidier 1895, Molet 1957). }\end{array}$ \\
\hline
\end{tabular}


TABLE 2 Correspondance between Wilmé et al.'s 'centers of endemism'/ 'retreat-dispersion watersheds' and 'endemism refugia' and 'dispersion refugia' as listed in Figure 1.

\begin{tabular}{|c|c|}
\hline Wilmé et al. 2006 & Toponyms \\
\hline 1 & Vohimarina \\
\hline A. Bemarivo & Bemarivo \\
\hline 2 & Masoala \\
\hline a2. Antainambalana & Antainambalana \\
\hline 2 & Analanjirofo \\
\hline B. Mangoro & Mangoro \\
\hline 3 & Tanala \\
\hline C. Manampatrana & Manampatrana \\
\hline 4 & Manombo \\
\hline D. Mananara Sud & Mananara Sud \\
\hline 5 & Anosy \\
\hline \multirow[t]{2}{*}{ d6. Mandrare } & Ranopiso \\
\hline & Mandrare \\
\hline 6 & Karimbola \\
\hline e6. Onilahy & Onilahy \\
\hline 6 & Mikea \\
\hline E. Mangoky & Mangoky \\
\hline 7 & Menabe \\
\hline F. Tsiribihina & Tsiribihina \\
\hline 8 & Melaky \\
\hline G. Betsiboka & Betsiboka \\
\hline 9 & Sofia \\
\hline H. Maevarano & Maevarano \\
\hline 10 & Ampasindava \\
\hline I. Sambirano & Sambirano \\
\hline 11 & Ankify \\
\hline J. Mahavavy North & Mahavavy North \\
\hline 12 & Ankarana \\
\hline
\end{tabular}

Mananara and Masoala, Atsinanana has also always been one of the major timber resources of the country (Petit and Jacob 1965). Its forests have been perceived as immeasurably large and its timber resources as being infinite. The notion that these forests could one day disappear seems so unlikely to the Malagasy that they proverbially regard these forests' disappearance to something that is totally impossible.

\section{Center of Endemism: TANALA}

Etymology: Malagasy tan = people of (generally, the prefix anand ante-, previously spelled antai- and several variants taken to indicate 'the people' or 'the person from'), and ala = forest or forests, to designate a group of people of the forest (Chapman 1940). Ranomafana National Park protects 41,600 ha of humid forest.

\section{Center of Endemism: MANOMBO}

Manombo Special Reserve has one littoral forest on sand and a second parcel on ferruginous soil (Rabevohitra et al. 1998). Manombo special Reserve contains 5,300 ha of humid and littoral forests.

\section{Center of Endemism: ANOSY}

Etymology: Malagasy Anosy = where islands occur (Grandidier 1895). Anosy also refers to the Anosy Mountains in southeast- ern Madagascar; it further represents an administrative unit since 4 October 2009. Andohahela National Park comprises three parcels: Parcel 1 (58,800 ha) covering humid forest and comprising of 45,100 ha in the Anosy Center of Endemism; Parcel 2 covering 12,800 ha, and Parcel 3 with 300 ha, both of dry-spiny forest-thicket (see Ranopiso Center of Endemism).

\section{Center of Endemism: RANOPISO}

Etymology: Malagasy rano $=$ water, and piso $=$ cat. In coastal areas, people talk about amany piso, which literally refers to 'cat's urine' to qualify a small volume of liquid, as in French. Ranopiso also refers to the main town in this small area situated between the humid eastern slope and the dry southern slope. Parcel 2 of Andohahela National Parks lies mainly (with 8,800 ha) within this center and Parcel 3 is entirely within Ranopiso Center of Endemism.

\section{Center of Endemism: KARIMBOLA}

The Karimbola is a southern region roughly delimited by the Menarandra and Manambovo rivers (Mahé and Sourdat 1972). It also refers to a clan of Mahafaly people (Bernard 1978). Tsimanampetsotsa National Park $(45,800$ ha) and Cap SainteMarie Special Reserve (2,900 ha) entail the driest forest type of Madagascar (south-western dry spiny forest-thicket, Moat and Smith 2007).

\section{Center of Endemism: MIKEA}

Etymology: mikaike = shout (imperative of); because, in order to meet the Mikea people in the forest, one has to shout loudly (Dina and Hoerner 1976). It also refers to an ethnic group and the only formally recognized 'indigenous peoples' in Malagasy, as defined by Operational Directive 4.20 (World Bank 1991). They are confined to the dry forests in southwestern Madagascar, with a harsh environment but one providing abundant food and material with which to build houses (Stiles 1998). The Mikea forest is defined as lying between the Manombo and Mangoky rivers, along a coastal strip west of the Antseva corridor (Molet 1958, 1966).

\section{Center of Endemism: MENABE}

Etymology: Malagasy mena = red, and be = big, to refer to the color of red soils and rivers loaded with those. The Menabe encompasses a large coastal region of western Madagascar, as illustrated by Schlemmer (1983) for the Kingdom of Menabe at the end of the $19^{\text {th }}$ century (cf. Figure 4 in Schlemmer 1983). Kirindy-Mitea $(81,000$ ha) National Park and Andranomena Special Reserve $(7,800$ ha) are composed of western dry forest (Moat and Smith 2007).

\section{Center of Endemism: MELAKY}

Melaky has been considered one of the 22 Regions of Madagascar since 4 October 2009, and is situated in the central western region. The ethnic group living in this region are the Sakalava, whose main activity is cattle herding, farming and fishing. Immigrants are primarily Merina, Betsileo, and people from the Bara and Vezo among others. Immigrants tend to be farmers, small-scale traders or manual laborers. There are seven protected areas within the Melaky mainly covering western dry forests; Ambohijanahary Special Reserve (24,300 ha) is the only protected humid forest in the Melaky. 
The Melaky region is crossed by an extensive network of rivers with a water plentiful throughout the year: these water resources are invaluable for many economic activities such as river and sea transport, water supplies, fisheries and agriculture. The lakes are important habitat, breeding and refuge sites for many water birds, including the Manambolomaty lake complex which holds 20 species or subspecies of waterfowl endemic to Madagascar including $10 \%$ of the global population of the Madagascar fish eagle, Haliaeetus vociferoides, as well as the endemic freshwater turtle Erymnochelys madagascariensis, which is in steep decline. Near these lakes, particular ecological conditions allow for the thriving of plant species like evergreen Securinega perrieri and commercially viable species like Commiphora sp., Cordylia madagascariensis, Dalbergia sp. and Hazomalania voyroni. The shores are also characterized by the abundance of species of baobabs Adansonia spp.

\section{Center of Endemism: SOFIA}

Etymology: Sofia has been the name of an administrative Region since 2009 as well as that of a main river of the region. Dandouan (1922) refers to Sofia as 'the beauty' in Kiswahili, but this is not confirmed (George Paul 2012 In litt.). The eastern part of Ankarafantsika National Park $(57,500$ ha out of 135,000 ha) lies within this center and covers western dry forest.

\section{Center of Endemism: AMPASINDAVA}

Etymology: Malagasy any = at, fasika = sand, and lava = long, which makes 'at the long beach'. The name also refers to the bay of Ampasindava. Mahilaka is the oldest trading port on coastal Madagascar, linking to East Africa and the Near East, as early as 11th centuries AD (Wright et al. 2005).

\section{Center of Endemism: ANKIFY}

Eponymy: Ankify refers to the region facing Nosy Be on the mainland, the Ankify Peninsula.

\section{Center of Endemism: ANKARANA}

Eponymy: Ankarana in Malagasy means 'where there are rocks' (Grandidier 1895). Ankarana consists of a limestone plateau that does not exceed $300 \mathrm{~m}$ a.s.I. and that slopes gently toward the east. To the west, where it is highest, the plateau ends abruptly creating a fortress called 'wall of Ankarana', stretching 25 $\mathrm{km}$ from north to south. The plateau is composed of Jurassic limestone, chalk in the upper and siliceous at the base (Cardiff and Befourouack 2007). Due to rainfall, these rocks have been heavily eroded: it forms karst where the majority of formations are eroded into fantastic shapes (e.g., tower karst, sinkholes). For three million years, rain has eroded the limestone massif summit, creating fields of sharp ridges. This is where the name tsingy originates (meaning 'walking on tiptoes').

Ankarana is a reference to the name of the ethnic group living in this region, the Antakarana, meaning 'those who inhabit the rocks'. In the nineteenth century, their kings took refuge in the limestone caves to escape the highland ethnic groups trying to conquer them, particularly during the last war with the King Radama I (Cardiff and Befourouack 2007). The caves are royal burial sites and are places of salutary significance on a spiritual level. The Antakarana organize annual ceremonies Fidirana an-davaka, meaning 'enter the hole', to honor their ancestors. Every five years, a ceremony (Tsangan-tsaina), or 'changing of the mast', is held.

This exceptional site is protected as a special reserve covering an area of 18,225 ha. It holds great biodiversity with its moist deciduous forests including bamboos, and on the rocks, sparse xerophytic flora adapted to extreme drought conditions.

\section{FLAGSHIP SPECIES OF THE CENTERS OF ENDEMISM}

In this section, one species for each center of endemism (CE) is presented according to the criteria described previously. Their biological traits and populations are briefly depicted, and where available, an illustrative oral legend or a traditional story is presented.

\section{CE: VOHIMARINA}

Propithecus tattersalli Simons 1988

English: golden-crowned sifaka

Malagasy: ankomba malandy

IUCN: Critically Endangered

CITES: Appendix I

Number of data points in Noe4D: 37

Number of references: 98

The species has been described recently from a few forest remnants in northeastern Madagascar (Figure 2a). Continuous conservation and research efforts revealed higher population densities than previously thought. For example in Andranotsimaty ('where the water does not stop', Malagasy an-rano-tsy-maty) adjacent to the Daraïna, the population density is higher than that of Eulemur coronatus, despite continuous mining activities: in an area of less than 100 ha there are around 20 groups of golden-crowned sifaka each composed of 5-8 individuals. The total population is between 6,000 and 10,000 and is threatened mainly because mining for gold, sapphire, quartz and other minerals attracts numerous immigrants who do not respect the local taboo or fady prohibiting eating of Propithecus. Increased human activities in the forests for timber products such as fire wood for cooking or construction adds pressure on these lemurs.

An interesting story associated lemurs in Madagascar in general is the following: In a particular household, the husband was very unhappy as his wife beat him on a regular basis. Such was his state of depression that he lost enthusiasm for life. His sadistic wife would not even allow him to drink rum. All day he had to work, in a prison-like marriage. One day, he addressed the God of the forest, saying: "God of the Forest, you can see how I have been unhappy for so long. You are my only hope, so please do something to help me". The God of the Forest was moved by the man's plight. So he transformed the man into a wonderful and agile animal, i.e., a lemur, allowing the man to escape his unhappy circumstances. And so originated the lemurs of Madagascar.

\section{CE: MASOALA}

Varecia rubra (É. Geoffroy 1812)

English: red ruffed lemur

Malagasy: varimena

IUCN: Endangered

CITES: -

Number of data points in Noe4D: 18 
Number of references: 95

The ruffed lemurs are the largest members of the family Lemuridae, and this species is the largest of the genus Varecia (Varecia v. variegata, V. v. editorum, V. v. subcincta). Long considered confined to Masoala Peninsula, it has been found as far north as the Andapa Basin (Figure 2b). It is impossible to confuse with other ruffed lemurs but cross-species hybridization has produced some surprising-looking individuals - all white, all black, or red, white and black. As in many other lemurs, females dominate groups of two to $20+$ individuals. Their diet consists of fruit, nectar and pollen, and includes leaves when fruits and flowers are scarcer. Females usually give birth to twins (Vasey 2005). Something distinctive about ruffed lemurs is their explosive, loud vocalizations. They are readily observable in Masoala National Park, particularly at Tampolo. Their habitat is threatened by slash and burn agriculture, illegal logging (e.g., rosewood and ebony) and consequently poaching and hunting

\section{CE: ANALANJIROFO}

Indri indri (Gmelin 1788)

English: indri

Malagasy: babakoto, endrina

IUCN: Endangered

CITES: Appendix I

Number of data points in Noe4D: 83

Number of references: 191

Considered largest of the extant lemurs, sometimes entirely white in color and sometimes entirely black (no genetic difference) according to locality, the Indri is a flagship animal of Madagascar. Their siren-like calls carry for miles and are the hall-mark sound of the island's rainforests. They are present on the east coast, from Mangoro watershed, up to Anjanaharibe Special Reserve, and the northern borders of Makira Natural Park (Figure 2c). They inhabit rainforest up to an altitude of 1800 m. Indris are diurnal, and move by jumping or bounding, even on the ground. Their diet consists of leaves and fruit and they live in groups of two to five individuals. Females are dominant, and are also larger than males. Indris are threatened by massive deforestation and the consequent fragmentation of remnants of eastern forests. Hunting and poaching in some areas pose a real threat while in others they are protected by fady so persecuting them is prohibited. Indris have never bred in captivity: this is probably because of their very specialised diet. Analamazaotra is the best site in which to see habituated Indri.

All Indri-related myths portray the species as a friendly animal and there is almost always a connection between indri and human origins, implying common ancestry. According to one legend, two brothers lived together in the forest. One day, one of the brothers decided to leave the forest and cultivate the land instead. He finally became the first human, but the brother who stayed in the forest became the first indri. That is why, until now, the indri still calls his brother from the forest daily.

\section{CE: TANALA}

Propithecus edwardsi A. Grandidier 1871

English: Milne-Edwards' sifaka

Malagasy: simpona

IUCN: Critically Endangered

CITES: Appendix I

Number of data points in Noe4D: 47
Number of references: 136

Long considered a subspecies of Propithecus diadema, but elevated to full species (Groves 2001, Mayor et al. 2004), the Milne-Edward's sifaka has experienced a population decline of $50 \%$ during the last 30 years, partly due to degradation and loss of its natural habitat. It is found along a narrow strip of forest near the southeast coast between the rivers Mangoro, Onive, Manampatrana and to the limits of the Andringitra National Park (Figure $2 \mathrm{~d}$ ). It frequents rainforest at an altitude ranging from 600 to 1600 m a.s.I. In Ranomafana National Park, its density is 7.6 individuals per $\mathrm{km}^{2}$, and it lives in groups of three to nine individuals. The species is diurnal and its diet consists of leaves, fruits, flowers and buds of some 25 known plant species (Hemingway 1998). Slash and burn agriculture is the main threat facing this charismatic species, diminishing its natural habitat and bringing about excessive fragmentation of forest remnants. Hunting is also a threat but only in the north of its range, because many people protect it further south. Because of its diet, the species does not survive in captivity.

\section{CE: MANOMBO}

Eulemur cinereiceps (Grandidier and Milne-Edwards 1890) English: white-collared lemur

Malagasy: varika

IUCN: Endangered

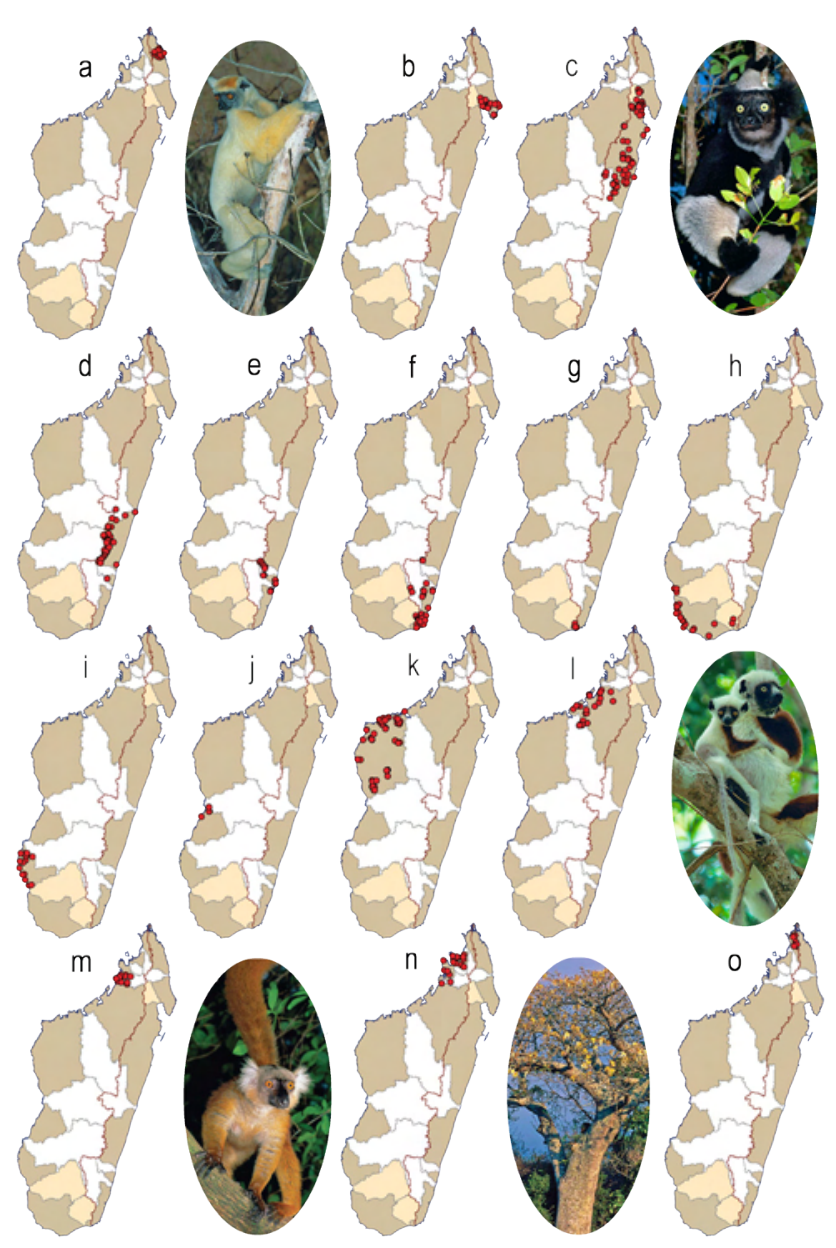

FIGURE 2. Distribution of the flagship species. (a) Propithecus tattersalli, (b) Varecia rubra, (c) Indri indri, (d) Propithecus edwardsi, (e) Eulemur cinereiceps, (f) Eulemur collaris, (g) Dypsis decaryi, (h) Coua verreauxi, (i) Monias benschi, (j) Hypogeomys antimena, (k) Propithecus deckeni, (I) Propithecus coquereli, (m) Eulemur flavifrons, (n) Eulemur macaco, (o) Adansonia perrieri 
CITES: -

Number of data points in Noe4D: 22

Number of references: 82

Formerly known as Eulemur albicollaris, which has been synonymized recently (Johnson et al. 2008). Some similarities with E. collaris can render identification more difficult, but differences in pelage on the upper limbs or cheeks are diagnostic Like all Eulemur spp., it is cathemeral, i.e., it is active by day and night, alternating phases of sleep and wakefulness; it moves on all fours while using its tail as balance and can cover long distances. The species lives in groups of four to 12. Its diet consists of fruit, leaves, flowers and fungi (Ralainasolo et al. 2008). It appears to have a life span of over 20 years. Its range is very restricted, ranging from rivers Manampatrana and Mananara in the southeast of the island (especially in protected areas of Manombo and Andringitra) (Figure 2e), where it frequents the interior of primeval rainforest. The population is estimated at between 2,500 and 7,000 but decreasing. Threats include loss of habitat (deforestation, logging, slash and burn agriculture and poaching) and also, hybridization with another Eulemur species, Eulemur rufifrons (Johnson and Wyner 2000).

\section{CE: ANOSY}

Eulemur collaris (É. Geoffroy 1812)

English: collared brown lemur

Malagasy: varika

IUCN: Vulnerable

CITES: Appendix I

Number of data points in Noe4D: 54

Number of references: 108

Eulemur collaris is restricted to southern Madagascar, to the north of Fort Dauphin (Tolagnaro) and Mananara River (Figure 2f). Its population has experienced a $30 \%$ decline over the past 24 years. Its population at Midongy-Sud is, however, remarkably high with around 14 individuals per $\mathrm{km}^{2}$. It lives in groups of three to 12 individuals in the eastern forests up to an altitude of $1800 \mathrm{~m}$ a.s.l. Groups are matriarchal and the species is cathemeral. Its diet is primarily frugivorous, but it will also consume sap, bark, buds, flowers, and some insects (e.g., centipedes) (Irwin et al. 2005). Anthropogenic pressures (hunting) and habitat destruction remain the key threats to its survival. It adapts well to conditions in captivity.

\section{CE: RANOPISO}

Dypsis decaryi (Jum.) Beentje \& J. Dransfield

English: triangulated palm

Malagasy: laafa

IUCN: Vulnerable

CITES: Appendix II

Number of data points in Tropicos: 5, 14 specimens

Number of references: 5

This highly unusual palm, which blooms all year long, is confined to a very small part of southern Madagascar (Figure $2 \mathrm{~h}$ ) where roughly 1,000 individuals are presumed to remain in the wild. Outside of Madagascar however, the species is cultivated in large numbers, in many countries as it grows quickly and seeds germinate fast (Dransfield and Beentje 1995, Ratsirarson 2003). It has a smooth and upright trunk, brownish-grey in colour and marked by scars from old fronds. Overlapping leaf-bases grow from three distinct points on the trunk, forming a triangle, hence the name triangulated palm. The leaves are pinnate and they arch almost upright, measuring approximately three meters in length and one meter in width. They are segmented and bluishgreen in colour. The petioles - about $1.3 \mathrm{~m}$ long - covered in yellowish-green blooms, support the leaves. The triangulated palm is monoecious, i.e., male and female flowers are found on the same plant. Flowers are followed by round, black fruit. Many seeds are exported for cultivation abroad.

\section{CE: KARIMBOLA}

Coua verreauxi Grandidier 1867

English: Verreaux's coua

Malagasy: arefy, tivoka

IUCN: Near Threatened

CITES: -

Number of data points in Noe4D: 25

Number of references: 120

The Verreaux's coua (Coua verreauxi) is a bird that is found only in areas of low elevation in southwest Madagascar. The distribution of $C$. verreauxi is relatively narrow in the southwest of Madagascar and the southern area of spiny forest (Tsimanapetsotsa, Cap Sainte-Marie and the Tsihombe region). In these areas its population is considered stable given the absence of specific threats (Figure 2i). The species was named after Jules Verreaux (1807-1873). Measuring about $38 \mathrm{~cm}$ its greenish-grey head is topped with a gray crest. The bare skin around the eyes, typical of this family, is ultramarine in the front and sky-blue behind the eyes. The iris is dark brown. The chin, throat and under-parts are white. The beak, tarsi and feet are black. The upper-parts and wings are a greenish-grey. The long tail is dark blue with metallic reflections, and marked with white on the outer tail feathers. Its diet consists of invertebrates hunted in trees and bushes and on the ground. Seasonally they also consume fruit of Cassia sp. (Cesalpiniaceae). The males call from treetops in November, suggesting that breeding occurs around this time. The main threat to this species is woodcutting for charcoal, which is common especially along the roads near the market towns.

There is an extract associated with this species and the origins of the radiated tortoise, taken from Decary (1964). The tivoka (the coua) and the fano (marine turtle) once had a conversation. The fano really wanted to visit the mainland so tivoka agreed to guide him. After some time, the turtle with its flattened legs, began to complain. The bird took pity on the turtle and using magic, altered the turtle's feet so it could walk comfortably. So the marine animal with its newly adapted legs continued exploring on land. Unfortunately at one point, the tivoka inadvertently defecated on the head of the turtle. Extremely irate, the turtle cursed its guide. Angry in turn, the bird deserted the turtle, refusing to change its legs back to their original shape. The fano, then wandered for the rest of its days on dry earth without ever finding the sea again. This legend refers to the origin of the land tortoises, specifically the Madagascar radiated tortoise.

\section{CE: MIKEA}

Monias benschi Oustalet \& Grandidier 1903

English: Bensch's mesite, subdesert mesite

Malagasy: naka

IUCN: Vulnerable

CITES: - 
Number of data points in Noe4D: 23

Number of references: 80

The sub-desert mesite is endemic to the southwest Mikea Forest between the Onilahy and the Mangoky watersheds (Figure 2j). It belongs to the endemic family of the Mesitornithidae. It is terrestrial, with long pinkish legs and with distinctive white eyebrows. The back is brownish-grey and the tail fairly long. The males have black spots on their white underparts, while underparts of females are variably mottled with reddishbrown and black. The bill is long and curved. It occurs in thorny Didiereaceae-Euphorbia thickets on sandy soil. It can tolerate severely degraded habitat. Its diet consists of invertebrates but also seeds, found by fossicking in leaf-litter, shallow water or by digging in the sand. Like all mesites, this species flies only to reach the roosting sites, nests, or, if hard pressed, to avoid predators. Reproduction occurs throughout the year, even during the middle of the dry season. This is possible because of termite mounds, at which they feed. The nest is a platform of twigs about $15 \mathrm{~cm}$ diameter and five centimeters deep, lined with fresh lichens. Some pairs can construct up to five nests in one breeding season, and one or two eggs are laid in each nest (Seddon et al. 2003).

\section{CE: MENABE}

Hypogeomys antimena A. Grandidier 1869

English: giant jumping rat

Malagasy: vosistse, votsotsa

IUCN: Endangered

CITES: -

Number of data points in Noe4D: 9

Number of references: 71

The hare-sized giant jumping rat (Hypogeomys antimena) is the largest rodent and the only monogamous rodent in Madagascar. It has long and pointed ears; a bulbous pink nose, short honey-coloured fur and large hind feet which enables it to hop like a miniature kangaroo around its dry, baobab-dominated forest home in the Menabe region. To escape predators, it can leap almost three feet into the air (Sommer 1996). This scarce endemic mammal, which inhabits a tiny range of just $400 \mathrm{~km}^{2}$ in which its seasonally dry forest habitat is highly fragmented, is best sought at Kirindy Forest, part of the Menabe protected area north of Morondava (Figure 2k).

A pair will maintain a territory of about four hectares, and in it, create a complex of tunnels, about $45 \mathrm{~cm}$ wide, and up to five meters long, and down to about one meter below the ground. Strictly nocturnal, they emerge at dusk to feed on fruit and seeds. Food is consumed in a manner similar to squirrels: it is held in the forepaws and placed into the animal's mouth while it sits semiupright on its haunches. One or two youngsters are usually born in the brief rainy season from December to March. The offspring remain with their parents for varying lengths of time: $2-3$ years if female and 1-2 years if male. Threats to the species include habitat loss due to slash and burn agriculture and predation from introduced species such as feral dogs and cats.

\section{CE: MELAKY}

Propithecus deckeni Peters 1870

English: Decken's sifaka

Malagasy: sifaka, tsibahaka

IUCN: Vulnerable
CITES: Appendix I

Number of data points in Noe4D: 56

Number of references: 65

Long considered a subspecies of Propithecus verreauxi but recently elevated to full species status (Groves 2005), this sifaka is found in disparate patches of forest in western Madagascar, between the Tsiribihina and Betsiboka watersheds (Figure 2l). Its exact distribution is difficult to define because the presence of $P$. coronatus; some hybridization between these two species has occurred (Thalmann et al. 2002). It inhabits the dry forests and lives in groups of two to ten individuals. It is found in the following protected areas: Tsingy de Bemaraha National Park, Baly Bay and the Ambohijanahary Special Reserves. The species' population has been reduced by $30 \%$ over the past 30 years. Threats to its habitat are continuous: forests are increasingly fragmented as trees are felled for charcoal production and to create pasture for grazing. However, there are also some very strong taboos preventing hunting of the species.

\section{CE: SOFIA}

Propithecus coquereli (A. Grandidier 1867)

English: Coquerel's sifaka

Malagasy: sifaka, tsibahaka

IUCN: Endangered

CITES: Appendix I

Number of data points in Noe4D: 33

Number of references: 78

Coquerel's sifaka is encountered in the Sofia region lying between Betsiboka and Maevarano watersheds (Figure $2 \mathrm{~m}$ ) and is mainly protected in the Ankarafantsika National Park (with about 60 individuals per $\mathrm{km}^{2}$ ) and at Anjajavy. Groups live within territories ranging from four to nine hectares. The species feeds on leaves, flowers, buds, fruits or bark depending on season (Ganzhorn 1988). The main threats which have led to a $50 \%$ decrease in its population over the last 30 years are destruction of its habitat (bush fires for pasture, logging, felling of trees for charcoal production) but also poaching by migrant people despite local taboos that prohibit hunting it. It is present in some zoological gardens including in the USA.

\section{CE: AMPASINDAVA}

Eulemur flavifrons (Gray 1867)

English: Sclater's lemur or blue-eyed black lemur

Malagasy: akomba sy manga maso

IUCN: Critically Endangered

CITES: Appendix I

Number of data points in Noe4D: 12

Number of references: 79

Long considered a subspecies of Eulemur macaco, E. flavifrons is now regarded as a full species (Mittermeier et al. 2008). It is found in a very narrow area on the peninsula Sahamalaza ('the famous valley') and in a thin strip of forest around Befotaka ('much mud') and south of the Manongarivo (Litt. 'above a thousand rivers', Grandidier 1895) (Figure 2n). For a hundred years until 1983, of its rediscovery, the scientific community raised many questions about its existence and survival. Today its population, which has decreased markedly, is estimated somewhere between 2,780 and 6,950 (Schwitzer et al. 2005). E. flavifrons is found in highly fragmented forests. The destruction of these fragments by shifting slash and burn cultivation 
threatens the remaining populations to an increasing extent. However, it seems well adapted to secondary forests. Groups consist of six to 10 individuals (usually four to seven adults) and are cathemeral. Like other Eulemur, their diet consists mainly of fruit and seasonally they consume leaves and flowers.

\section{CE: ANKIFY}

Eulemur macaco (Linnaeus 1766)

English: black lemur

Malagasy: ankomba joby

IUCN: Vulnerable

CITES: Appendix I

Number of data points in Noe4D: 20

Number of references: 70

It was for a long time considered that this species included two subspecies: Eulemur m. macaco and E. macaco flavifrons), until 2006 when all the subspecies of Eulemur spp. were elevated to full species, the black lemur being E. macaco (Mittermeier et al. 2008). Morphological and genetic differences between the two species led to this distinction. Eulemur macaco is found from the Mahavavy river east to the river of Ambilobe Andranomalaza ('water-famous', Malagasy and-rano-malaza), in forests and to Ampasindava and Nosy Faly (the 'happy island') and also on the islands of Nosy Tanikely ('the small island of land') and Nosy Komba where it was introduced (Figure 20). Where it coexists with E. flavifrons in some areas, the two species do hybridize. Black lemurs easily adapt to modified habitat, and like other Eulemur spp. are cathemeral, moving in martiarchal groups of two to 15 individuals. Their diet is varied although mostly frugivorous. As with many lemurs they are agents of seed dispersal, as some species of tree require a passage through the gut of an animal in order to germinate (Birkinshaw 1999). Major threats to this species include the destruction of its natural habitat, poaching and domestication. However they are easily bred in captivity and reintroduction programs could be established in the case of increased human pressure.

\section{CE: ANKARANA}

Adansonia perrieri Capuron 1960

English: Perrier's baobab

Malagasy: bozy

IUCN: Endangered

CITES: -

Number of data points in Noe4D and Tropicos: 4 and 9, 12 specimens

\section{Number of references: 3}

The baobabs belong to the genus Adansonia (Malvaceae) with one species in Africa (A. digitata) also introduced to Madagascar, one species in Australia and six endemic species to Madagascar. Madagascar is clearly the center of baobab diversity but the genus originated in Africa (Baum et al. 1998). A. perrieri opens its flower during the night and produces most of its nectar between $2100 \mathrm{~h}$ and $0300 \mathrm{~h}$. It is primarily pollinated by large hawkmoths with body sized of 5-6 $\mathrm{cm}$ and proboscides exceeding $20 \mathrm{~cm}$. Among these hawkmoths, Xanthopan morgani has been reported to visit Perrier's baobab flowers at anthesis. $X$. morgani is the pollinator that was predicted to exist by Darwin for a Malagasy orchid and the Malagasy subspecies has thus been named $X$. morgani praedicta (Baum 1995). It is confined to the northern region, where it has been recorded from five sites
(Figure 2p). Only one of them, Ambondromifehy, contains more than a dozen individuals. This baobab is threatened by habitat destruction, especially bush fires, the collecting of firewood and illegal logging. Rats as seed predators also pose a significant threat. It is said to occur in Analamerana Special Reserve.

Legends surrounding baobabs invariably point towards their common nickname of 'upside-down tree'. One example is that baobabs were initially graceful trees, which delighted in boasting about their aesthetic qualities, much to the annoyance of other, more uninteresting-looking trees. In response to complaints by the other trees, God saw to it that seeds of baobabs sprouted upside-down and the roots grew upwards, and the branches down into the earth. Similarly, an Arabian legend pertaining to the Malagasy baobabs (known as za, ringy or boringy) holds that the devil ripped out the baobab, planted its branches into the earth, and left its roots in the air. Another legend referring to the 'upside down tree' claims that a long time ago, the baobab wanted to be the most beautiful of all trees. On realizing this was not the case, it became angry and buried its canopy, leaving the roots at the top.

\section{FINAL REMARKS}

Wilmé et al.'s 2006 watershed approach demonstrates that riparian forests in Madagascar have had an important role in geological times as refuges for fauna and flora. Riparian forests are also dispersion corridors and in some instances were probably able to link eastern with western slopes; in dry periods they can act as retreat and in wetter periods act as dispersion routes. These possible palaeoroutes between opposite slopes are still in need of documentation, but their existence could also explain the difficulty of finding a latitudinal pattern in plant or animal diversity. We therefore recommend considering riparian forests as important components for conservation biodiversity under climate change.

For clear communication at national and international levels, a proper naming of a place or region according to standardized rules is crucial (Andriamihaja 1984). Our sense of locality is clearly expressed in terms of names of places or regions. Toponymy has the potential to enrich the understanding of local environments, which can also create a culturally appropriate curriculum. Biodiversity and its endemic features, here represented by the centers of endemism and the 15 flagship species, contribute to peoples' attachment to a particular place and become part of a person's identity (Horwitz et al. 2002).

\section{REFERENCES}

Andriamihaja, S. 1984. Aperçu sur la toponymie nationale et internationale [y compris note de la Direction de la revue, GD - Gérald Donque]. Madagascar, Revue de Géographie 45: 49-61.

Baum, D. A. 1995. The comparative pollination and floral biology of baobabs (Adansonia, Bombacaceae). Annals of the Missouri Botanical Garden 82: 322-348.

Baum, D. A., Small, R. L. and Wendel, J. F. 1998. Biogeography and floral evolution of baobabs (Adansonia, Bombacaceae) as inferred from multiple data sets. Systematic Biology 47, 2: 181-207. (doi: 10.1080/106351598260879)

Bernard, A. 1978. Essai sur la transition de la société Mahafaly vers les rapports marchands. Travaux et documents de I'Orstom 90. ORSTOM, Paris.

Birkinshaw 1999. The importance of the black lemur (Eulemur macaco) for seed dispersal in Lokobe forest, Nosy Be. In: New Directions in Lemur Studies. H. Rasaminanana, B. Rakotosamimanana, J. Ganzhorn and S. Goodman (eds.), pp 189-199. Plenum Press, New York. 
Cardiff, S. G. \& Befourouack, J. 2007. La Réserve spéciale de I'Ankarana. In: Paysages Naturels et Biodiversité de Madagascar. S. M. Goodman (ed.), pp 571-584. Muséum national d'Histoire naturelle, Paris

Chapman, O. M. 1940. Primitive tribes in Madagascar. The Geographical Journal 96, 1: 14-25.

Conedera, M., Vassere, S., Neff, C., Meurer, M. and Krebs, P. 2007. Using toponymy to reconstruct past land use: A case study of 'brüsada' (burn) in southern Switzerland. Journal of Historical Geography 33, 4 729-748. (doi:10.1016/j.jhg.2006.11.002)

Cornet, A. \& Guillaumet, J.-L. 1976. Divisions floristiques à étages de végétation à Madagascar. Cahiers de I'ORSTOM, Série Biologie 11, 1: 35-42.

Dandouan, A. 1922. Géographie de Madagascar. Émile Larose, LibraireÉditeur, Paris.

Decary, R. 1964. Contes et Légendes du Sud-ouest de Madagascar. Maisonneuve et Larose, Paris.

Dewar, R. E. and Richard, A. F. 2007. Evolution in the hypervariable environment of Madagascar. Proceedings of the National Academy of Sciences of the United States of America 104, 34: 13723-13727. (doi:10.1073/pnas.0704346104)

Dewar, R. E., Radimilahy, C., Rasolofomampianina, L. D. and Wright, H. T. 2010. Early settlement in the region of Fenoarivo Atsinanana. In: Civilisations des Mondes Insulaires (Madagascar, îles du canal du Mozambique, Mascareignes, Polynésie, Guyanes). C. Radimilahy \& N. Rajaonarimanana (eds.), pp 677-740. Karthala, Paris.

Dina, J. \& Hoerner, J. M. 1976. Étude sur les populations Mikea du Sud-ouest de Madagascar. Omaly sy Anio 3-4: 269-286.

Dransfield, J. and Beentje, H. 1995. The Palms of Madagascar. Royal Botanic Gardens and the International Palm Society, Kew.

Ganzhorn, J. U. 1988. Food partitioning among Malagasy primates. Oecologia 75, 3: 436-450. (doi:10.1007/BF00376949)

Goodman, S. M. and Benstead, J. P. 2005. Updated estimates of biotic diversity and endemism for Madagascar. Oryx 39, 1: 73-77. (doi: 10.1017/ S0030605305000128)

Grandidier, A. 1895. Des principaux noms de lieux de Madagascar et de leur signification. Bulletin du Comité de Madagascar 1, 5: 211-222.

Groves, C. P. 2001. Primate Taxonomy. Smithsonian Institution Press, Washington D.C.

Groves, C. P. 2005. Order Primates. In: Mammal Species of the World. A Taxonomic and Geographic Reference. Third edition. D. E. Wilson and D. M. Reeder (eds.), pp 111-184. The Johns Hopkins University Press, Baltimore.

Hemingway, C. A. 1998. Selectivity and variability in the diet of MilneEdwards' Sifakas (Propithecus diadema edwardsi): Implications for folivory and seed-eating. International Journal of Primatology 19, 2 355-377. (doi:10.1023/A:1020344018670)

Hertu, O. \& Elouard, J.-M. 2001. Logiciels NOE et CartoNOE. In: Biodiversité et Biotypologie des Eaux Continentales de Madagascar, pp 361-381. Institut de Recherche pour le Développement (IRD) \& Centre Nationa de la Recherche pour l'Environnement (CNRE).

Horvath, J. E., Weisrock, D. W., Embry, S. L., Fiorentino, I., Balhoff, J. P., Kappeler, P., Wray, G. A., Willard, H. F. and Yoder, A. D. 2008. Development and application of a phylogenomic toolkit: Resolving the evolutionary history of Madagascar's lemurs. Genome Research 18: 489-499. (doi:10.1101/gr.7265208)

Horwitz, P., Lindsay, M. and O'Connor, M. 2002. Biodiversity, endemism, sense of place, and public health: Inter-relationships for Australian inland aquatic systems. Ecosystem Health, 7, 4: 253-265. (doi:10.1046/ j.1526-0992.2001.01044.x

Humbert, H. 1965. Description des types de végétation. In: Notice de la Carte de Madagascar. H. Humbert \& G. Cours Darne (eds.), pp 46-78. Travaux de la Section Scientifique et Technique de I'Institut Français de Pondichéry, Hors série 6.

Irwin, M. T., Johnson, S. E. and Wright, P. C. 2005. The state of lemur conser vation in south-eastern Madagascar: Population and habitat assessments for diurnal and cathemeral lemurs using surveys, satellite imagery and GIS. Oryx 39, 2: 204-218. (doi:10.1017/S0030605305000451)

Johnson, S. E. and Wyner, Y. 2000. Notes of the biogeography of Eulemur fulvus albocollaris. Lemur News 5: 25-28.
Johnson, S. E., Lei, R., Martin, S. K., Irwin, M. T. and Louis, E. E. 2008. Does Eulemur cinereiceps exist? Preliminary evidence from genetics and ground surveys in southeastern Madagascar. American Journal of Primatology 70, 4: 372-385. (doi:10.1002/ajp.20501)

Kadmon, N. 2000. Toponymy: The Lore, Laws and Language of Geographical Names. Vantage Press, New York.

Krause, D. W. 2010. Washed up in Madagascar. Nature 463: 613-614. (doi:10.1038/463613a)

Mahé, J. \& Sourdat, M. 1972. Sur l'extinction des vertébrés subfossiles et I'aridification du climat dans le Sud-Ouest de Madagascar. Description des gisements, datations absolues. Bulletin de la Société Géologique de France, 7e sér. 14, 1-5: 295-309.

Martin, R. D. 1972. Review lecture: Adaptive radiation and behaviour of the Malagasy lemurs. Philosophical Transactions of the Royal Society B: Biological Sciences 264, 862: 295-352. (doi:10.1098/rstb.1972.0013)

Mayor, M. I., Sommer, J. A., Houck, M. L., Zaonarivelo, J. R., Wright, P. C., Ingram, C., Engel, S. R. and Louis Jr., E. E. 2004. Specific status of Propithecus spp. International Journal of Primatology 25, 4: 875-900. (doi:10.1023/B:IJOP.0000029127.31190.e9)

Mittermeier, R. A., Ganzhorn, J. U., Konstant, W. R., Glander, K., Tattersall, I., Groves, C. P., Rylands, A. B., Hapke, A., Ratsimbazafy, J., Mayor, M. I., Louis Jr, E. E., Rumpler, Y., Schwitzer, C. and Rasoloarison, R. M. 2008. Lemur diversity in Madagascar. International Journal of Primatology 29 6: 1607-1616. (doi:10.1007/s10764-008-9317-y)

Moat, J. and Smith, P. 2007. Atlas of the Vegetation of Madagascar. Kew Publishing, Royal Botanic Gardens, Kew.

Molet, L. 1957. Petit Guide de Toponymie Malgache. Publications de I'Institut de Recherche Scientifique de Madagascar, Section des Sciences Humaines, Tananarive.

Molet, L. 1958. Aperçu sur un groupe nomade de la forêt épineuse des Mikea. Bulletin de l'Académie Malgache 36: 241-243.

Molet, L. 1966. Les Mikea de Madagascar ou vivre sans boire. Revue de Madagascar 36: 11-16.

Perrier de la Bâthie, H. 1921. La végétation malgache. Annales du Musée Colonial de Marseille série 3, 9: 1-273 + i-vi.

Petit, M. \& Jacob, G. 1965. Un essai de colonisation dans la baie de I'Antongil. Annales de I'Université de Madagascar, Lettres 4: 33-56.

Raherilalao, M. J. \& Wilmé, L. 2008. L'avifaune des forêts sèches malgaches. In: Les Forêts Sèches de Madagascar. S. M. Goodman \& L. Wilmé (eds.), pp 76-105. Malagasy Nature 1.

Ralainasolo, F., Ratsimbazafy, J. and Stevens, N. J. 2008. Behavior and diet of the Critically Endangered Eulemur cinereiceps in Manombo forest, southeast Madagascar. Madagascar Conservation \& Development 3, 1: $38-43$.

Ratsirarson, J. 2003. Dypsis decaryi, Triangle Palm. In: The Natural History of Madagascar. S. M. Goodman and J. P. Benstead (eds.), pp 457-459. The University of Chicago Press, Chicago.

Reddy, S., Driskell, A., Rabosky, D. L., Hackett, S. J. and Schulenberg, T. S. 2012. Diversification and the adaptive radiation of the vangas of Madagascar. Proceedings of the Royal Society B. (doi:10.1098/ rspb.2011.2380)

Schlemmer, B. 1983. Le Menabe: Histoire d'une Colonisation. Éditions de I'ORSTOM,X Paris.

Schwitzer, C., Schwitzer, N., Randriatahina, G. H. and Kaumanns, W. 2005. Inventory of the Eulemur macaco flavifrons population in the Sahamalaza protected area, northwest Madagascar, with notes on an unusual colour variant of E. macaco. Primate Report Special Issue 72 , 1: $39-40$.

Seddon, N., Tobias, J. A. and Butchart, S. H. M. 2003. Group living, breeding behaviour and territoriality in the Subdesert Mesite Monias benschi. Ibis 145, 2: 277-294. (doi:10.1046/j.1474-919X.2003.00150.x)

Sommer, S. 1996. Ecology and social structure of Hypogeomys antimena, an endemic rodent of the dry deciduous forest in western Madagascar. In: Biogéographie de Madagascar. W. R. Lourenço (ed.), pp 295-302. Éditions de l’ORSTOM, Paris

Stiles, D. 1998. The Mikea hunter-gatherers of southwest Madagascar: Ecology and socioeconomics. African Study Monographs 19, 3 : $127-148$ 
Thalmann, U., Kümmerli, R. and Zaramody, A. 2002. Why Propithecus verreauxi deckeni and $P$. v. coronatus are valid taxa - quantitative and qualitative arguments. Lemur News 7: 11-16.

Vasey, N. 2005. Activity budgets and activity rhythms in red ruffed lemurs (Varecia rubra) on the Masoala Peninsula, Madagascar: Seasonality and reproductive energetics. American Journal of Primatology 66, 1: 23-44. (doi:10.1002/ajp.20126)

Vérin, P. 1986. The History of Civilisation in North Madagascar. A. A. Balkema, Rotterdam.

Wilmé, L., Goodman, S. M. and Ganzhorn, J. U. 2006. Biogeographic evolution of Madagascar's microendemic biota. Science 312: 1063-1065. (doi:10.1126/science.1122806)

World Bank. 1991. Operational Directive 4.20: Indigenous Peoples in W. Bank, editor. World Bank, Geneva.

Wright, H. T., Radimilahy, C. \& Allibert, C. 2005. L'évolution des systèmes d'installation dans la baie d'Ampasindava et à Nosy-Be. Taloha 14-15. Available at <http://www.taloha.info/document.php?id=137>

Yoder, A. D. 2003. Phylogeny of the lemurs. In: The Natural History of Madagascar. S. M. Goodman and J. P. Benstead (eds.), pp 1242-1247. The University of Chicago Press, Chicago.

Yoder, A. D. and Nowak, M. D. 2006. Has vicariance or dispersal been the predominant biogeographic force in Madagascar? Only time will tell. Annual Review of Ecology, Evolution, and Systematics 37: 405-431. (doi:10.1146/annurev.ecolsys.37.091305.110239)

\section{SUPPLEMENTARY MATERIAL.}

AVAILABLE ONLINE ONLY.

TABLE S1. Table listing the documents (with lat/long/time/specimen\#/ref) for each of the Data Points in Figure 2.

TABLE S2. Table of references for the 15 species (775 references) 